

\section{Crisis Spaces}

The financial malaise that has affected the Eurozone countries of Southern Europe - Spain, Portugal, Italy and, in its most extreme case, Greece - has been analysed using mainly macroeconomic and financial explanations.

This book shifts the emphasis from macroeconomics to the relationship between uneven geographical development, financialisation and politics. It deconstructs the myth that debt, both public and private, in Southern Europe is the sole outcome of the spendthrift ways of Greece, Spain, Italy and Portugal, offering a fresh perspective on the material, social and ideological parameters of the economic crisis and the spaces where it unfolded.

Featuring a range of case examples that complement and expand the main discussion, Crisis Spaces will appeal to students and scholars of human geography, economics, regional development, political science, cultural studies and social movements studies.

Costis Hadjimichalis is Professor Emeritus in the Department of Geography at Harokopio University of Athens, Greece. He previously held a post in the Department of Urban and Regional Planning at Aristotle University of Thessaloniki, and has been a visiting professor at different universities in Europe, the USA and Australia. His current research and publications concern uneven geographical development, local and regional development, radical geography and landscape analysis. He has been the section editor of the Regional Development section in the International Encyclopaedia of Human Geography. Among his recent books are Space in Left Thought (co-author Dina Vaiou, 2012 in Greek), Debt Crisis and Land Dispossession (2014 in Greek, 2016 in German) and Geographical Issues Suited to Non-Geographers (2016 in Greek). 


\section{Routledge Studies in Human Geography}

This series provides a forum for innovative, vibrant and critical debate within Human Geography. Titles will reflect the wealth of research that is taking place in this diverse and ever-expanding field. Contributions will be drawn from the main sub-disciplines and from innovative areas of work that have no particular sub-disciplinary allegiances.

For a full list of titles in this series, please visit www.routledge.com/series/ SE0514

65 Public Urban Space, Gender and Segregation

Women-only urban parks in Iran

Reza Arjmand

66 Island Geographies

Essays and Conversations

Edited by Elaine Stratford

67 Participatory Research in More-than-Human Worlds

Edited by Michelle Bastian, Owain Jones, Niamh Moore

and Emma Roe

68 Carceral Mobilities

Interrogating movement in incarceration

Edited by Jennifer Turner and Kimberley Peters

69 Mobilising Design

Edited by Justin Spinney, Suzanne Reimer and Philip Pinch

70 Place, Diversity and Solidarity

Edited by Stijn Oosterlynck, Nick Schuermans and Maarten Loopmans

71 Towards A Political Economy of Resource Dependent Regions

Greg Halseth and Laura Ryser

72 Crisis Spaces

Structures, Struggles and Solidarity in Southern Europe

Costis Hadjimichalis 


\section{Crisis Spaces}

Structures, Struggles and Solidarity

in Southern Europe

\section{Costis Hadjimichalis}

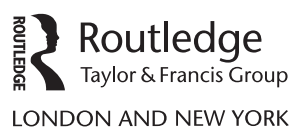


First published 2018

by Routledge

2 Park Square, Milton Park, Abingdon, Oxon OX14 4RN

and by Routledge

711 Third Avenue, New York, NY 10017

Routledge is an imprint of the Taylor \& Francis Group, an informa business

(C) 2018 Costis Hadjimichalis

The right of Costis Hadjimichalis to be identified as author

of this work has been asserted by him in accordance with sections 77 and 78 of the Copyright, Designs and Patents Act 1988.

All rights reserved. No part of this book may be reprinted or reproduced or utilised in any form or by any electronic, mechanical, or other means, now known or hereafter invented, including photocopying and recording, or in any information storage or retrieval system, without permission in writing from the publishers.

Trademark notice: Product or corporate names may be trademarks or registered trademarks, and are used only for identification and explanation without intent to infringe.

British Library Cataloguing-in-Publication Data

A catalogue record for this book is available from the British Library

Library of Congress Cataloging-in-Publication Data

A catalog record for this book has been requested

ISBN: 978-1-138-18450-3 (hbk)

ISBN: 978-1-315-64513-1 (ebk)

Typeset in Times New Roman by codeMantra 
"The bread we eat in this world, the water we drink the strength of our knees, the taste of our skin is for resistance (contest) not for our escape..."

By the Turkish Poet Turgut Uyar, (1927-1985), re-written on the walls in Gezi Park during its occupation in 2013. Translated by Pelin Tan 
This page intentionally left blank 


\section{Contents}

List of figures viii

List of tables $\quad \mathrm{x}$

List of boxes $\quad$ xi

Preface and acknowledgments xii

1 Introduction 1

2 Uneven development I: capital restructuring and changes in the spatial division of labour before the euro 15

3 Uneven development II: capitalist transformation and the building of the Eurozone

4 "It is your fault": imagining and constructing the new "Southern Question"

5 De-politicising uneven development and socio-spatial justice

6 "Nobody alone in the crisis": resistance and solidarity 138

$\begin{array}{lll}7 & \text { Politics of hope or the time of monsters? } & 178\end{array}$

References 191

Index 


\section{Figures}

1.1 Italian businessman exits a "bunga-bunga party" (Berlusconi's term) and one reads that Italy is now in crisis

3.1 USA: Value added as percentage of GDP for selected sectors, 1945-2015

3.2 GERMANY: Gross value added as percentage to GDP for selected sectors, 1995-2015

3.3 GREECE: Gross value added as percentage of GDP for selected sectors, 1995-2015

3.4 ITALY: Gross value added as percentage of GDP for selected sectors, 1995-2015

3.5 SPAIN: Gross value added as percentage of GDP for selected sectors, 1995-2015

3.6 PORTUGAL: Gross value added as percentage of GDP for selected sectors, 1995-2015

3.7 Real house price index for Germany, Greece, Ireland, Italy, Portugal and Spain, 2000-2015 (Index, 2010 = 100 rescaled to $2000=100$ )

3.8 Competitiveness of Germany, Italy, Spain, Portugal and Greece, 1995-2015

3.9 Germany's value of exports to Southern Europe, the USA, China and Japan, 1995-2007 (Southern Europe refers to Greece, Italy, Portugal and Spain)

3.10 Trade balance with Germany: Greece, Italy, Portugal and Spain, 1995-2015

3.11 Nominal unit labour costs in Germany, Greece, Italy, Spain and Portugal, 1995-2015

3.12 Fiscal balance of Germany, Greece, Italy, Portugal and Spain, 1995-2015 (GDP\%)

3.13 Public debt for Germany, Greece, Italy, Portugal and Spain, 1995-2015 (GDP\%)

4.1 The PIGS eat money from structural funds and EU taxpayers

4.2 Bild newspaper article 
4.3 "Made in Germany lies" 96

4.4 Fake blinds: A. Petroulakis cartoon 98

4.5 Lagarde: "Greeks have to pay!" The Troika refuses

a proposition by the Greek government to tax wealthy citizens

4.6 The myth of European solidarity 101

4.7 Negotiation begins: Schäuble: "We insist on making soap from your fat and to discuss the fertilisers from your ashes" 102

4.8 “...Hey!...this way Madame!". Ch. Lagarde and W. Schäuble guide a medieval army, besieging the castle of Greece

5.1 Unemployment in the European Union, Germany, Greece, Italy, Portugal and Spain, 1985-2015 


\section{Tables}

2.1 Micro, small and medium enterprises in SE and EU, 2012

2.2 Imports of semi-finished and final products (sector TAC) in Italy according to areas of origin (in millions euro, \%, 1991-2001)

2.3 Migrant employment by economic activity, 1998-1999 (in \%) 38

3.1 The ratio of constructions to GDP, 1995-2013 (in \%) 53

3.2 Regional clustering of footwear firms and employment and crisis (different years)

5.1 Income inequality in Southern Europe 1980-2014, Gini coefficient

5.2 Risk of poverty, $\%$ of total population

5.3 Severe material deprivation, \% total population 129

5.4 Youth unemployment as \% of total population below 30 years 131

5.5 Early school leavers 131

5.6 Mean number of healthy years, 2009-2013, total change 133 


\section{Boxes}

1.1 Greece's secret deal 7

2.1 A socialist Southern Europe? 16

2.2 Third Italy 18

2.3 The Maastricht Treaty: financial colonialism redux 23

2.4 Mergers and acquisitions in the Italian textile-clothing
sector and in the Greek food sector

2.5 Moving frontiers 35

2.6 Factories in the fields: racism in El Ejido and
Nea Manolada

3.1 Profits from rents 46

3.2 Planning at the service of real estate 55

3.3 Real estate scandals 57

3.4 Crisis in the Southern European footwear industry 67

3.5 Public land and public assets dispossessions in Greece
during the crisis

4.1 Prejudices from the past 83

4.2 The "discovery" of the Balkans 91

4.3 Political and economic scandals in SE 97

5.1 Critique of social capital 112

5.2 How the rich get richer during the crisis 124

5.3 Crisis and austerity policies increase socio-spatial
inequalities

5.4 Brain drain from SE 132

6.1 Occupied social centres in Italy 144

6.2 A black day in the anti-austerity struggle 150

6.3 "No signal", occupying public broadcaster ERT in Athens 155

6.4 Types and groups of AAOs as in LIVEWHAT research 158

6.5 The Athens social solidarity clinic 166 


\section{Preface and acknowledgments}

Ten years have passed since the first signs of the crisis in Southern Europe emerged, and several parameters are by now well known. Dozens of books and hundreds of papers have been written using mainly macroeconomic and financial explanations. So, is it worth another book? Although I don't deny the importance of macroeconomics, in this book I shall shift the emphasis to a missing, or not well-studied, parameter, namely uneven geographical development and its relation to financialisation. I challenge the dominant view that debt, public and private, is the sole cause of the crisis. On the contrary, I argue it is the outcome of the longue durée of uneven capitalist development, not the single reason for the current turmoil in the (EU) European Union.

What happens in my country, Greece, makes me angry, and I have the same feelings for what happens in other countries in Europe, especially Southern Europe. I am aware that victims of imperialism, neoliberalism and austerity and the tragic waste of human lives exist everywhere and perhaps to a greater degree. We remember what happened a few years back in the Balkans and now in the wars in Syria, Iraq, Afghanistan and several countries of Africa. These wars are responsible for thousands of victims and refugees - men, women and children - losing their lives, most recently in the Mediterranean while escaping to Europe through its southern shores. This book, however, is about the victims of another war - this time without military acts but with the weapons of world finance and the imposition of ultra-austerity policies and dispossessions that have similar outrageous effects: deaths, emigration, hungry people and lost sovereignty in an otherwise "peaceful" situation. This book is about the crisis in Southern Europe and my frustration with what happens there, being myself a Southern European and right in the midst of it. I know that in writing a book, anger is a bad companion, and I feel obliged to warn the reader about the strength of my viewpoint and the terms under which I write.

Crises historically help capitalism to reproduce and reconstitute itself and to open new avenues for capital accumulation. Hence, the mantra "crises create opportunities" is constantly repeated without asking for whom and at what cost. Crises, however, also change the way we see things, modifying our thoughts and understanding of the world around us. The latter is con-

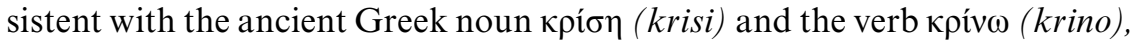


which mean, in both Ancient and Modern Greek, the ability to judge, to appreciate, to assess and to rethink. The Modern Latin crisis comes from the Greek noun кpí⿴囗 ( $k r i s i)$, but crisis as we know and use the word today has lost the meaning of the original. The book at hand uses both Greek and Modern Latin meanings. It tries to judge and rethink current crises in Southern European economies and societies in a different way, putting uneven geographical capitalist development at the centre of its analysis.

In doing this, I had invaluable help and encouragement from many friends, colleagues and comrades. The list begins with Dina Vaiou and Ray Hudson. I am grateful to both of them for reading and commenting on most of the chapters and making constructive suggestions. I am sure that they feel relief, as I do, at seeing the project completed. I benefited a lot from discussions and comments in various places and on different sections of the book, as well as from advice and data provisions from many people. So, let me record my thanks to the following: Abel Albet, Marco Armiero, Bernd Bellina, Nuria Benach, Marina Bertoncin, Rita Calvario, Myrto Hatzimichali, Evangelia Chatzikonstantinou, Giacomo D' Alisa, David Featherstone, Soledad Garcia Cabeza, Haris Golemis, Ares Kalandides, Haris Konstantatos, Maria Kousis, Olga Lafazani, Petro Marques, Enzo Mingione, Akis Papataxiarchis, Diane Perrons, Andrew Sayer, Dimitra Siatitsa, Sofia Skordili, Céline Spieker, Pelin Tan, Fereniki Vatavali and Antoni Ybarra.

Particular thanks also to David Harvey for his continuous radical inspiration and for his encouragement to finish writing by kindly asking on several of his visits to Athens and Syros "when is it coming out?" In my journey, I have missed, however, two other close friends and teachers: Ed Soja and Doreen Massey. Both of them, although for different reasons, have been "there", influencing my thinking.

I benefitted from comments and debates with participants in several conferences and seminars across Europe and the USA that have helped sharpen the argument, and from the technical assistance of my research students Thanasis Lagridis and Sotiris Koskoletos. My English editor in Greece, Robyian Easty, corrected my "Greeklish" with patience, while also pointing out several inconsistences in the text.

Many thanks also to the following cartoonists and photographers for permission to use their art work: T. Anastasiou, C. Chappate, Coco Huang, B. Guble, Fotos movimento/Mónica Parra, Y. Ioannou, A. Petroulakis, C. Ritzler of BILD newspaper, D. Trumble and W. Warren. Also to the following newspapers: Avgi, BILD, Kathimerini, Globe and Mail, Efimerida ton Syntakton and New York Times.

Finally, I could not write this book without intellectual inspiration and encouragement - although they are not aware of it - from a large group of radical people in Greece, in other European countries and elsewhere with whom I feel politically close. And from a smaller, but very dynamic, group of radical students whom I have the privilege to work with - to this last group, the book is dedicated. 
This page intentionally left blank 


\section{Introduction}

In October 2013, I gave a talk in Brussels, invited by the (EU) European Union Directorate General for Regional Development. The session theme was "Spatial Justice in Future European Regional Development" and was organised by the Regional Studies Association, Open Universities Sessions. At that time, the crisis in Greece and in Southern Europe (hereafter SE) was fully developed; the harsh austerity policies of the Troika (the (IMF) International Monetary Fund, the EU and the (ECB) European Central Bank) since 2010 didn't provide positive macroeconomic results, while the negative effects on people were noticeable everywhere. Skyrocketing unemployment - particularly among the youth and women - salary and pension cuts, destruction of the welfare system, dispossessions of public property plus arrogance and hypocrisy among domestic and European elites made my SE fellow citizens and myself indignant. Feelings of injustice and despair fuelled demonstrations, general strikes and square occupations, making headlines around the world.

At that period, I was working on socio-spatial justice in Europe, based on my view that uneven geographical development lies behind the crisis in the EU and the Eurozone. I argued that debt, which everyone believed caused the crisis, is but one of the effects of the crisis and not its main cause. The longue durée of uneven geographical development in Europe and the uneven and undemocratic Eurozone structure was the fragile and explosive background upon which the global financial crisis was grounded and hit its first weak link, Greece. I wrote my paper along these lines, and as you would expect, there was deafening silence in the room. No one asked anything or commented. During the break, however, I had an intense conversation with three colleagues. In short, their argument was that my view is typical of Southern people's behaviour, always blaming others instead of analysing their own mistakes. I replied that this is often true, but the same can be said for EU politicians and the Troika who blame only SE instead of giving equivalent attention to their policies, to the unequal intra-European trade and the problematic Eurozone architecture, not to speak of the role of major European banks holding southern state bonds. My colleagues became more aggressive. "But we rescued you, we gave you a lot of our taxpayer's money and you sound so ungrateful", said one German regional economist. 


\section{Introduction}

And another, from Finland I think, added "... but anyway, you have to pay your debt back". "As we do", added the third one, from Spain. I felt I was in a tight corner, but I replied that Greek and other SE debts, particularly the Italian debt, are unsustainable, and without a political decision to cut at least part of them, they could never be repaid ... as the allies did with Germany in 1953. "But you are obliged to pay back our money; you are guilty", replied the German and Finnish colleagues, in angry tones. At that point, I realized that their statements were moving away from regional science and economic geography to become moral judgements. Although I had heard similar moral statements about the debt crisis before, in this particular case, they were, I felt, bereft of justifying arguments. The end of the break rescued me, but I was really annoyed and offended. Later, at that meeting, I decided that a reply with more complete/detailed arguments was needed, and this book is a partial outcome.

\section{Setting the scene}

... The blue sea, exotic beaches, bright Aegean light, hospitable locals, islands (...) make Greece an ideal holiday location. It's a country drenched in sunlight, living by the sea the year round!

Greek tourist advertisement, May 2016

There is a lot of sun and bright light in SE so that everything seems all too clear. For thousands of tourists coming down Park Guëll in Barcelona, navigating upstream on the Douro, getting lost in the medieval streets of San Gimignano or relaxing on one of Naxos' "exotic beaches", the crisis in SE that everybody has been speaking about since 2010 seems invisible. Particularly on summer nights when you see all bars and coffee shops full of young people, locals included, you may ask, "Where is the crisis?" This was the reply by Silvio Berlusconi, the former Italian Prime Minister, when he was asked whether Italy was in crisis, an argument repeated by other European politicians.

However, bright light and bodily performances in tourist places, as in the advertisement for Greece, is poor evidence for understanding the underlying local social processes. Seasonality, labour conditions and low pay in these tourist places are the worst in Europe and remain invisible or of no interest to tourists. Away from tourist areas, in large cities and rural areas of the interior, ultra-austerity measures imposed since 2010 have had extreme negative economic, social and environmental effects. Austerity was the price paid by local societies in exchange for billions in financial support by the Troika to Greece and Portugal to pay back their national debts to foreign banks. Spain and Italy also imposed ultra-austerity programmes to avoid their inclusion in similar programmes. ${ }^{1}$ By 2014, Greece had lost 15 per cent of its (GDP) Gross Domestic Product in four years, 
unemployment had risen to 27.5 per cent (58.8 per cent for young people), 34.6 per cent of the population were at risk of poverty, one-third was cut off from public health and the government was forced to sell off public land and public utility companies. Greece perhaps led the way in SE. Nevertheless, similar figures can be observed in the three other countries as well. By 2014, unemployment was 26.2 per cent in Spain (55.5 per cent for the young), 17.0 per cent in Portugal (37.7 per cent) and 13.5 per cent in Italy (40 per cent). In Spain 27.3 per cent of the population was at risk of poverty by 2014 , in Portugal 25.3 per cent and in Italy 28.4 per cent. These are sad figures and show how ridiculous and insane the so-called "recovery plans" and "structural reforms" were, based on austerity and the "shock doctrine", wasting the most important asset - people and, particularly, the youth and women. Not all people, however, suffered during the years of austerity. A minority of the richest 10 per cent increased their wealth compared to the rest of the adult population. Following a 2016 report by Credit Suisse, ${ }^{2}$ in 2010 the richest 10 per cent of Greeks owned 38.8 per cent of the national wealth, while by 2016 the 10 per cent had increased its wealth to 54.0 per cent. Similar figures exist for other SE countries; austerity is a class warfare indeed and the rich class that is the aggressor is winning.

Parallel to economic and political wars, ideological wars and geographical imaginations supported arguments for "lazy Greeks", "irresponsible Portuguese", "all the time partying Spaniards" and "dolce vita enjoying Italians" (see Figure 1.1).

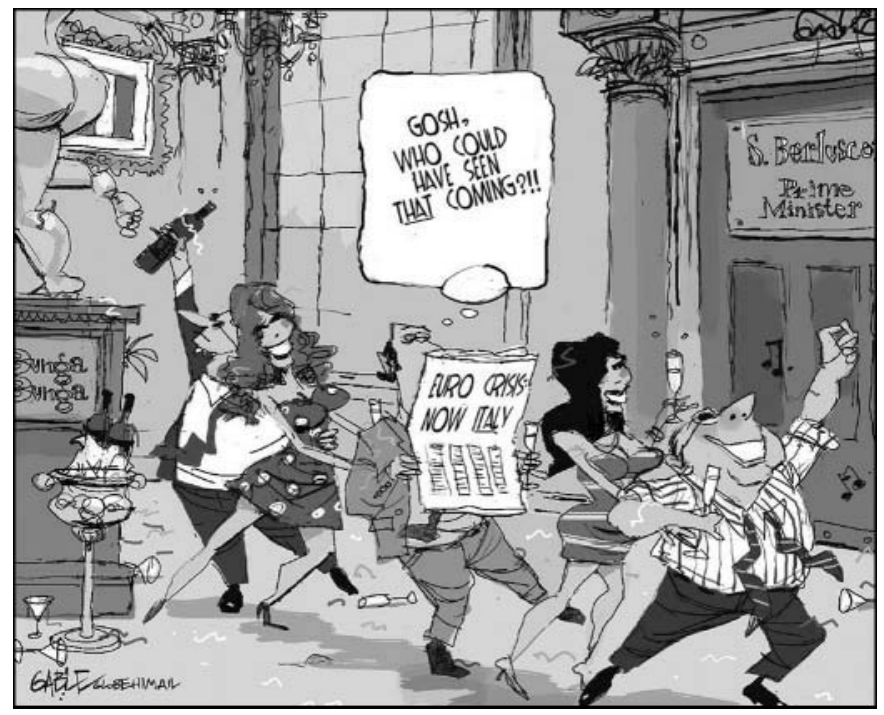

Figure 1.1 Italian businessman exits a "bunga-bunga party" (Berlusconi's term) and one reads that Italy is now in crisis.

Source: Brian Gable from Globe and Mail, July 2011. 
Here, it is particularly helpful to remember Antonio Gramsci and his writings about Southern Italy:

...(for) the propagandists of the bourgeoisie...if the South is backward, the fault does not lie with the capitalist system or any other historical cause, but with Nature, which made the Southerners lazy, incapable, criminal and barbaric.

Antonio Gramsci, "Some Aspects of the Southern Question", in: Selections from Political Writings, 1926/1978: 444

A century passed after Gramsci wrote the above quote about Southern Italy, describing how the press, novels, articles and other dominant ideological institutions represent Southern people as "biologically inferior beings". Today, a critique of arguments naturalizing uneven socio-spatial relations in capitalism seems timely for the entire SE. In fact, from the beginning of the crisis, the dominant narrative used by European and domestic leaders focussed exclusively on SE internal inefficiencies and their tricks to fool the state, using a more nuanced language. Popularised by mainstream media and spread far and wide, the revival of old prejudices paved the way for persuading political audiences in Europe that austerity policies were what Southern people deserved and what should be used by central-northern countries to discipline them. Responsibility for the loss of economic dynamism in SE lay with the unions who strike, the inefficient state apparatus, the pensioners with high pensions, the young people who demand higher education, the universities, the political parties... We are all guilty.

I am not denying the existence of some truth in these arguments, and I do not intend to ignore the many deficiencies and corruption of SE societies and governments. ${ }^{3}$ In the following pages, you will read many detailed descriptions of such instances. However, I would like to stress from the beginning a major concern: What happens in a particular place and society depends always on the contradictory articulation between internal/endogenous and external/exogenous conditions. Cities, regions and countries are not closed, bounded entities but are open and porous; their firms, people and institutions interact, building relations at multiple scales, from local to global and vice versa. European unification and the Eurozone intensified openness with the free circulation of capital but less so of labour. There is a shifting importance between these conditions, which are always uneven and combined in particular places and times. But uneven capitalist development is never exclusively endogenous or exogenous, because capital accumulation presupposes value circulation across space at the highest speed possible. Political and economic elites always advertise their successful policies during phases of prosperity, but try to deny their responsibility in cases of crisis, using internal or external causes as explanations. In the current case of SE, the invocation 
by capital and politicians, domestic and international alike, of the responsibility of entire Southern societies conceals their own "grey" role. The uneven socio-spatial structure of the EU and the unequal terms of trade and integration into the Eurozone, which meant the accumulation of debts in the South and surpluses in the North, became simply outrageous (Hadjimichalis, 2011; Lapavitsas et al., 2012; Bellina, 2013; A. Smith, 2013). Thus, national governments in Central-Northern Europe, the mainstream media and the Troika became across-the-board accusers and started blaming the victims for their debts on the basis that attack is the best form of defence.

Since then, the creditor-debtor moral obligation has been transformed into a mechanism of government with particular means of control of political and social behaviour in SE. Debt creation under neoliberalism became the prime power relation between creditors and debtors without questioning how and by whom the debt appeared in the first place and whether it is sustainable. Thus, according to Maurizio Lazzarato (2012), debt functions: "... as a mechanism for the production and 'government' of collective and individual subjects" (p. 29), and, Lazzarato continues:

...it takes a particular form of homo economicus, the "indebted man". The creditor-debtor relationship encompasses capital/labor, welfare state services/users and business/consumer relations, just at it cuts through them, instituting users, workers and consumers as "debtors".

(p. 30, emphasis in the original)

The indebted Man, or "homo debtor", according to Lazzarato (2012), now occupies the entire public space. Within the power relationship of debtorcreditor, Lazzarato argues, "homo debtor" is free insofar as his way of life is compatible with reimbursement. Entire societies and whole populations become indebted, producing collective subjugation, "populous debtor". Historically, debt has been used by colonising countries to exert control, and there has always been a connection between debt and guilt, as David Graeber (2011) argues, adding the dimension of morality to the uneven power relations. This is especially true in the German culture where the word for "debt" - schuld - famously also means "guilt". Debt defines the limits of actions and political behaviour by political leaders and people, not the other way around. For example, how "free" are indebted countries to choose a new government in elections? Direct anti-democratic interventions by the EU in Greece and Italy - where elected governments have been overthrown to be replaced by bankers - shows the new power of debt morality and resembles Foucault's definition: an action from a distance carried out on another action, which keeps entire societies "free" but disciplined and loyal to creditors.

One among the many myths about the crisis in SE is that it all started in 2008 to 2009 without any reference to the past. It is the direct effect of the 


\section{Introduction}

US mortgage crisis, which, by crossing the Atlantic, became a sovereign debt crisis. Until this period, European economies operated normally without problems: thus, it is clear that the crisis was due to external reasons. These narratives of the crisis succumb to what Guldi and Armitage (2014) call "short-termism", the preferred framework of economists being the immediate past, say 15-20 years, ignoring conditions present over longer periods. The Short Past has become the dogma in postmodern neoliberal economics and the framework for explanations of and policies dealing with the current crisis. This is also evident in the term "crisis" in bourgeois economics that signals a situation of disruption, a break from a prior situation of normality or stability. It demands immediate action to avoid some kind of danger, to return to normality. In capitalism, it means that some unforeseen, destructive feature inserts itself into a supposedly "normally functioning" period. Crises, however, in Marxist political economy are essential to the reproduction of capitalism and, through "creative destructions", open new possibilities and spaces for further capital accumulation and expansion. From 1970 until 2000, we had 23 major global economic crises, and from 2000 until 2015, we had one every year (see www.caprasia.com). Hence, one may ask: When was capitalism not in crisis? Dominant answers to this question take crisis-free capitalist reproduction for granted, and when crisis happens, it is explained without any reference to the past because it is a "radical break". Marx, however, reminds us that no social change occurs, for the better or the worse, which is not already latent within pre-existing conditions.

No doubt something very dramatic indeed happened in the EU and in the Eurozone during the period from 2007-2010. The first phase of the crisis was in August 2007 when the largest French bank, BNP Paribas, declared the closure of three of its investment funds because of the inability to finance them. The second phase started in mid-2007 with the collapse of the US housing market and the wave of foreclosures - a very material-geographical starting point indeed, but its effects spread quickly around the world to become a global crisis with the Lehman Brothers credit crunch in September 2008. The European Council, in October of the same year, promised financial support to those banks facing overexposure problems due to non-performing loans. The global crisis initially hit two weak interrelated European sectors: banks and real estate. The first signs were noticed in Spain's real estate sector (particularly housing and tourism real estate), in the former communist countries of Eastern Europe and in the Irish banking sector. To this should be added Iceland's bankrupt financial sector, a non-EU country but with many financial ties with EU banks.

The third phase of the crisis started in November 2009, when Greece became the new crisis epicentre of global capitalism, attracting headlines all over the world. With a huge public deficit of 12.7 per cent of GDP (October 2009) and an equally huge public debt of almost 300 billion euros, or around 113 per cent of GDP, it is no surprise that the country has 
been into the "sausage grinder of the financial markets and international banks" (Golemis, 2010: 129) as they are the principal holders of Greek state bonds. At the same time, an aggressive attack by international financial speculators began, increasing the cost of borrowing from international institutions. The immediate trigger in the Greek case came in February 2010 when the so-called "socialist" government of (PASOK) the Panhellenic Socialist Movement was forced to seek refinancing for more than 60 billion euros of debt. During the heady days of irrational financial speculation of the late 20th and early 21 st centuries, global banking institutions "conspired" with the Greek government to conceal the extent of the debt holdings of the country.

\section{Box 1.1 Greece's secret deal}

The journal Spiegel, usually echoing the position of the German government, in its electronic version (2 August 2010), describes how Greece's debt managers agreed to a huge deal with the savvy bankers of the US investment bank Goldman Sachs at the start of 2002. The deal involved so-called "crosscurrency" swaps in which government debt issued in dollars and yen was swapped for euro debt for a certain period to be exchanged back into the original currencies at a later date. Such transactions are part of "normal" and "legitimate" government refinancing, uncontrolled by Maastricht rules. But in the Greek case - as happened with Italy and even France in previous years - the US bankers devised a special kind of swap with fictional exchange rates. This enabled Greece to receive a far higher sum than the actual euro market value of 10 billion dollars or yen and thus to enter the Eurozone with a 1.2 per cent of GDP deficit. In that way, Goldman Sachs secretly arranged additional credit up to 1 billion dollars for the Greeks.

Due to the specific organisation of the Eurozone and the inability of ECB to act as the "lender of last resort", the crisis caused a sobering up, and skittish investors downgraded Greece's risk rating and withdrew from further refinancing, causing the February crisis and finally the intervention by the Troika. Then it was Ireland in 2010 and Portugal in 2011 who, under severe pressure, asked for similar intervention by the Troika. Spain and Italy, having similar high debt levels, avoided the Troika's intervention but committed themselves to hard austerity measures and fiscal reform from 2011 onwards. Spain, with the help of the ECB, created a 99 billion euro bailout fund to rescue its vulnerable banks, shifting the burden to pension and salary cuts. Finally, Cyprus in 2012 also asked for the Troika's support for its banks. Different economic conditions and political decisions lie behind each case. However, as all governments moved in to bailout banks and financial institutions with taxpayers' money, public debt became a common problem to 


\section{Introduction}

all, together with cuts in public spending, introducing deep recession and widespread poverty.

Why did that happen? Undoubtedly, the global financial crisis, as a conjuncture, played a decisive role in revealing every country's weak points. But an explanation focussing exclusively on this "break" and the rise of debt, public and private, seems less convincing. My supplementary hypothesis contains three elements. First, the roots of the crisis are embedded in uneven geographical/regional development, which characterised the socio-spatial structure of the EU long before the crisis, at least since the 1980s, combining endogenous and exogenous elements. Public debt is not the sole cause of the current crisis but one among many of its manifestations, while its roots are located in the gradual decline of southern regions' productive and export performance. Second, SE economies participated, to varying degrees, in a major capitalist transformation characterised by a shift from productive to rent-seeking activities, from the primary to the secondary circuit of capital. This transformation provides "thrive profits to rentiers while work does not pay", as Standing (2016) powerfully argues, and it is visible in most developed economies of the global North, particularly in the USA (see also Harvey, 2010; M. Hudson, 2010; Sayer, 2015), but, interestingly enough, not in Germany. A major parameter in this transformation relates to the rise of the so-called "FIRE" sectors, i.e. Finance, Insurance and Real Estate. It is not accidental that the first signs of the crisis in SE were found in sectors belonging to these "rent-seeking" activities: finance and real estate. And third, in the context of neoliberal hegemony, particular elites and regional hegemonic blocs in Central European countries (in the original EU-6 and above all in Germany) designed the Maastricht Treaty and the euro to conform to the characteristics and needs of their economies. In addition, in order to discuss the problems of the euro, they established undemocratic, nonelected institutions such as the Euro Working Group, which, together with other unaccountable EU institutions, form powerful multi-scalar lobbies to promote capital's interests. In doing this, they took advantage of the inevitable social and spatial restructuring that accompanied the introduction of the euro to regain political and economic control, not only vis-à-vis global financial markets but within the EU as well. This restructuring was based on pre-euro conditions of uneven economic and geographical development within the EU, which accelerated and intensified after the introduction of the euro to become the crisis-driven restructuring we face today.

Uneven geographical development as a framework enables us to approach the roots of the crisis in a dialectical way. Contradictory and multi-scalar processes such as fixity and motion, territorialisation and de-territorialisation, the flow of capital and information across space, the relative immobility of labour, place-specific devaluations, path dependency and institutions regulating all the above produce and reproduce uneven geographical development. The social and competitive organisational space under capitalism introduces monopolistic competition providing quasi-rents to certain 
sectors and locations while marginalising others. Unevenness across space and sectors is not a mere sidebar to how capitalism works but fundamental to its reproduction (Harvey, 1982, 2010; R. Hudson, 2005). Whatever it's particular source, uneven geographical development is a contributing factor to the creation and maintenance of individual and collective inequalities and hence to social and spatial injustices (Soja, 2010). To act against these injustices requires a politically sensitive approach towards development. In addition, it requires multi-scalar institutional and informal networks of solidarity, from global to national and to local/regional scales. Socio-spatial justice and socio-spatial solidarity are principles and values of progressive planning, neglected today under the neoliberalism ideology, which promotes de-politicisation. I strongly believe that we always need to talk about socio-spatial justice and socio-spatial solidarity in periods of crisis, such as the current crisis in the EU, in the context of which a discussion on theories, principles and values becomes more than imperative.

Related to social, political and spatial justice are social movements in SE cities that are resisting austerity with demonstrations, square occupations and networks of solidarity, highlighting once more that urban space and place matter. Since 2008, and particularly since 2010, there have been hundreds of bottom-up resistance and solidarity social movements all over the cities of Spain, Portugal, Italy and Greece. Building upon militant experiences of the 1990s and the 2000s, recent social movements in SE have shown that many people in these countries are active radical agents of resistance and solidarity, not passive victims of crude ultra-neoliberal policies. In addition, they are demonstrating the inadequacy of traditional progressive political forces of social democracy and the left.

\section{The Eurozone crisis meets Antonio Gramsci}

From the beginning of the crisis, EU and Eurozone non-elected institutions repeatedly showed arrogant and authoritarian characteristics, reminiscent of Nicos Poulantzas' analysis of "authoritarian statism". Elected governments were forced to step down and replaced by bankers; national Parliaments were replaced by unconstitutional agreements, so-called "Memoranda", as with the Troika. The role of the European Parliament was reduced, while the ECB's role was strengthened; private interests increasingly intruded into public decision-making; national sovereignty was equated with financial credibility, meaning that if you lose the second, you lose the first as well (Monde-Diplomatique, 9 December 2012). In Athens and Lisbon (and Dublin and later Nicosia), Troika's "men in black" dictated austere economic and social policies, while Madrid and Rome implemented austerity under the threat of similar interventions. In order to understand this anti-democratic turn in European politics, I found it useful to revisit Antonio Gramsci, a perceptive observer of the 1930s crisis. EU institutions were long ago accused of having permanent democratic deficits. 
During the crisis, however, the EU and Troika's policies became even more authoritarian, displaying what Gramsci described for the 1930s as "ceasarism", an appropriate description of European politics in the 21st century (Monde-Diplomatique, 9 December 2012). According to Gramsci, during capitalist crises, public institutions elected by universal voting, such as parliaments, are pushed into the background. Crisis conditions are strengthened instead:

...the relative power of bureaucracies (political and military), high ranking financial circles, the Church and in general all institutions which are unaccountable.

("War of movements and war of positions", Selections from Prison

Notebooks, 1971: 345)

In the Eurozone, a case par excellence is the Eurogroup. It is an informal institution, as dogmatic and exclusive as the Church, where finance ministers from the euro countries - quite often without an economics degree - participate "as friends", with an appointed president, without any democratic accountability and without official minutes, even though they dictate the conditions of everyday life for millions of Europeans. To his credit, Yanis Varoufakis, the first Syriza finance minister, exposed officially the undemocratic procedures of this peculiar and exclusive "Euro club" in several of his interviews. The way the Eurogroup reacted, together with other unaccountable institutions such as the ECB and EU bureaucrats, against the Greek referendum in July 2015, against the centre-left Portuguese government in 2016 and against the British Brexit in June of the same year, is indicative of this "ceasarism".

Gramsci, a prominent Italian Marxist and founder of the Italian Communist Party (Partito Comunista Italiano, PCI), studied in depth the unification of the Italian state, the Risorgimento. He analysed how the unevenly developed, economically and culturally, Italian regions were unified "from above", without any democratic popular participation, under the dominance of the northern bourgeoisie in alliance with Southern landlords (latifundisti) (Nardone, 1971). Although "history does not repeat itself" and major differences exist between the Risorgimento and the construction of the EU and the Eurozone, both processes have a common characteristic: capital and particular elites guiding both with the total exclusion of the popular masses. Gramsci is also known as a spatial theorist for taking account of the particular geographical embeddedness of historical phenomena (Jessop, 2005a; Ekers et al., 2013; Featherstone, 2013). For him, space and place are related with everyday life, with common sense and with collective memory, arguing that social and cultural identities have a spatio-temporal depth (Vaiou and Hadjimichalis, 2012). In this context, he made interesting observations on the conditions of uneven development between Northern and Southern Italy in various writings and especially in his essay "Some Aspects of the Southern Question" (in: Selections from Political Writings (1921-1926/1978). Central to Gramsci's views of uneven development, apart 
from capital's expansion, is the role of the state during the Risorgimento and the cultural and political unevenness between Northern and Southern Italy (the Mezzogiorno). Gramsci didn't have a theory of uneven development as such but a vantage point from which to theorise about socio-spatial inequalities, which could turn against the weakest part if counter-active policies were not enacted. He gives an example describing the articulation between the fiscal and customs systems of the new Italian state, with mobile capital making localised accumulation in Southern Italy impossible "on the spot":

...Any accumulation of capital on the spot, any accumulation of savings, is made impossible by the fiscal and customs system, and by the fact that the capitalists who own shares do not transform their profits into new capital on the spot, because they are not from that spot

(Some Aspects of the Southern Question, p. 16, op. cit.)

These observations at the beginning of the 20th century are timely today, while keeping in mind major differences between then and now. They constitute useful starting points to analyse the current crisis in the Eurozone, and I note four of them below. First, Gramsci's attention not only to capital accumulation but also to the articulation between capital accumulation, politics, political parties, cultural differences, institutions and above all to the role of the state provides a useful framework to understand the current crisis in the EU and the Eurozone. Here, particularly useful are his points on "ceasarism" during crises and the strengthening of unaccountable institutions. Second, although he is a prime analyst of the conjuncture, in doing this he always takes into account the historical and socio-spatial roots of the conjuncture. Third, his attention to specific cultural and economic characteristics, to class alliances and to the role of regional hegemonic blocks enables him to understand the difficulties in building solidarity across boundaries among working people. But he insists on the necessity of solidarity among culturally and geographically different subaltern classes. This point is particularly useful in understanding the sporadic expressions of solidarity towards SE people by others during the crisis in Europe, with the notable exception of those belonging to the left, to anarchism and to some organised trade unions. At the same time, Gramsci provides the basis for opposing prejudices used by both sides, Northern Italians accusing Southerners and vice versa. And fourth, uneven development between North and South in Italy is analysed using capital accumulation processes but also by going beyond them, with an analysis of different subaltern geographies of connection between the South and North, particularly the role of migration.

\section{This book}

My analysis focusses on Portugal, Spain, Italy and Greece. When I refer to them, I am aware that I don't include the complete geographical area of SE, but my choice is based on the fact that these four belong to the Eurozone, 


\section{Introduction}

and they have faced severe crises since 2009-2010. The four countries and their regions share significant dissimilarities as well as similarities, Italy being the third EU economy (after Brexit) and Spain the fourth, while Greece accounts for only 2 per cent of EU GDP. But, as I explain in the following chapters, there are other good reasons to study them together. Throughout the book, I give particular attention to politics and particularly to their spatialisation and scale as important regulatory frameworks. Due to particular SE traditions, national and regional political parties, from the left to the extreme right, have played key roles, and this is true for local bottom-up social movements. I give attention to both because they do politics at different scales, and the scalar approach helps us to understand the labyrinth of SE politics.

In Chapter 2, I deal with uneven development before the euro, from the 1980 s to the late 1990s. I give particular attention to several common characteristics in SE, such as the dominance of small and medium enterprises (SMEs), the informal sector, the fragmentation of regional labour markets, the role of the family and the role of the weak, clientelistic and familistic state. These characteristics allowed the rise of what I call dynamic "intermediate" regions that faced severe problems in the 1990s after crucial changes in the European and global division of labour. The Maastricht Treaty was a major turning point. It institutionalised neoliberalism and by transferring major regulatory powers to EU bodies it badly affected southern states, gradually destroying their national financial systems and their regional productive structures. Thus, SE regions and states, with variegated economic and institutional dynamism among them and more so compared with the central-northern areas, entered the Eurozone ill-prepared, deepening the intra- and inter-regional unevenness.

Chapter 3 discusses capitalist transformation and the building of the Eurozone. Here I challenge the dominant view that debt, public and private, is the sole cause of the crisis, arguing that it is the combined outcome of financialisation and the longue durée of uneven capitalist development. To support my argument, I look first at deeper capitalist transformations towards financialisation, particularly investment in assets and profiting from different types of rents, thus making a switch from the primary to the secondary circuits of capital. I focus especially on real estate, a geographical sector par excellence, and its boom-bust cycle that preceded the Eurozone turmoil. Then, I discuss the formation of the Eurozone, highlighting the absence of a geographical and regional perspective in the so-called "national convergence criteria" and argue that uneven development and uneven trade flows, not only debt, tell the story of the crisis. At the end of the chapter, I discuss the hybrid space/scale of the Eurozone and the role of undemocratic multi-scalar governance that fuelled the effects of the crisis and made it impossible for EU elites to solve any problem that had not been foreseen.

In Chapter 4, I shift the emphasis to ideological wars, to imagining and constructing the New "Southern Question". From the beginning of the 
crisis, dominant elites and the mainstream media constructed a narrative that framed Southerners who "live beyond their means" and "their" governments who systematically cheat EU institutions as the sole cause of the crisis. Starting with the famous "PIGS in Muck" story, I discuss geographical imaginations and prejudices about the South that have a long history but remained dormant during the years of prosperity. I discuss the geographical imagination and historical determinism of Robert Kaplan, a senior fellow at the Center for a New American Security, his static, deterministic and essentialist view of geography and history. In the last section, I present a short overview of prejudices and stereotypes used by politicians and the mainstream media against SE people and governments, as they have been published in newspaper articles and in cartoons.

Chapter 5 deals with the problem of the de-politicisation of uneven development, focussing on my field, economic geography and regional and urban planning. I argue that the gradual shift of major theories of economic geography and regional development towards "Third Way" thinking became a new de-politicised orthodoxy at a time when neoliberalism made a frontal attack in the field. This has made it easy to absorb their views into neoliberal policies, and when the crisis began, there was only one paradigm on the table - the neoliberal one. In this respect, both before and after the crisis, EU policies related to regional and urban inequalities were practically absent, other than for the rhetoric of "social and territorial cohesion". Thus socio-spatial inequalities increased dramatically after the crisis, resulting in severe injustices. The unfair terrain of the Eurozone and socio-spatial injustices among states and regions are further discussed using particular examples and data on unemployment, the risk of poverty, severe material deprivation, brain drain and energy misery.

Chapter 6 enters the terrain of resistance and solidarity in SE. It focusses on demonstrations, squares occupations and solidarity social movements in urban areas that resisted harsh austerity policies. These movements challenge de-politicisation as the main characteristic of neoliberal austerity via the spatialisation of democratic policies. The chapter makes a link between past and present SE militant left traditions and analyses the new political subjectivities that came out of mass demonstrations and the occupation of squares. These include Rossio in Lisbon, Puerta del Sol in Madrid, Plaza Cataluña in Barcelona and Syntagma Square in Athens. Finally, it discusses the extensive network of bottom-up, self-organised solidarity movements that spread across SE to provide urgent assistance to those in need, focussing on three Greek paradigmatic examples: the provision of food by the "food without middlemen" movement, the health solidarity services of self-organised "social clinics" and solidarity movements supporting migrants and refugees.

Finally, Chapter 7 discusses politics and poses questions about the future of the EU and the Eurozone. Are there any politics of hope, or do we face the time of monsters, as Gramsci predicted from his fascist prison in Italy before the Second World War? The chapter discusses developments after the 


\section{Introduction}

60th "birthday" celebration of the EU in Rome. It criticises the "multiple speed" proposal as the new European paradigm that rationalises and institutionalises the very causes of the crisis, namely uneven geographical development. At the end, I offer some thoughts on possible politics of hope, based on my own SE experience, imagining a kind of anti-capitalist utopian pragmatism.

Writing this book I several times faced the question of whether surveillance and actions by the Troika are legal and legitimate. The short answer is a strong no, also supported by decisions of supreme courts, which declared as illegal many policies imposed in cases such as lay-offs, pension cuts and dispossessions. Greece is again the extreme case, still being under continuous surveillance and control at the time of finishing this book. Portugal remained under similar conditions until 2014, but the EU and ECB continue all kinds of "interventions", as they do in Spain and Italy, particularly the tough surveillance of their banks and national budgets. The latter is the application of the new, undemocratic, economic governance of the EU, established in 2010, after the Greek crisis. All these actions support the idea that world finance used SE as a mode of warfare in developed economies, convincing the governments in the four countries to pursue policies that destroyed, to different degrees, their own economies. Giorgio Agamben (1998) calls forth the notion of "condition of exception" as a governance model based on the distinction between the juridical order over a particular place and another order in which people are deprived of similar juridical protection. In the absent of a unified juridical-political space, like the EU, dominant elites could exercise the particular spacing of exception by declaring a state of emergency due to the ideology of "crisis as break", as happened with the Troika and the Memoranda. In this situation, what is at stake is not only what actions and policies are considered legal and legitimate but also what lives or forms of lives count. In other words, do we accept a canonical process of life management, an ordering of space, that allows, as Gregory (2004) suggested, conquest "without taking the land", although the latter can be materialized by dispossessions? Do we accept that the Troika and other EU institutions are able to intervene in everyday political decisions from a distance, using debt as a battering ram?

\section{Notes}

1 We need to remember that Hungary, Latvia and Romania were the first countries to apply the painful IMF and EU programmes to stabilise the exchange rate. Austerity policies resulted in the well-known devastating effects: deep recession, high unemployment and severe cuts in social protection.

2 The Credit Suisse report defines as net wealth the value of financial assets plus real estate assets owned by households minus debts. Private pension fund assets are included, but not entitlements to state pensions.

3 Notwithstanding the complicity of big German corporations in the biggest scandals in Greece, for example, the legality of bribes by German companies, only recently revoked, and the huge amounts lost to fraudulent welfare payments in the UK. 


\section{References}

Abellàn, J. , Sequera, J. , Janoschka, M. (2012) "Occupying the \#Hotelmadrid: a laboratoty of urban resistance", Social Movements Studies, 11(3-4): 320-326.

Accornero, G. , Ramos Pinto, P. (2015) “'Mild Mannered'? Protest and mobilisation in Portugal under austerity, 2010-2013", West European Politics, 38(3): 491-515.

Agamben, G. (1998) Homo Sacer: Sovereign Power and Bare Life, Stanford: Stanford University Press.

Aglietta, M. (2000) "Shareholder value and corporate governance: some tricky questions", Economy and Society, 29(1): 146-159.

Akin, O. , García Montalvo, J. , García Villar, J. , Peydró, J.L. , Raya, J.M. (2014) "The real estate and credit bubble: evidence from Spain", www.researchgate.net/publication/265013899. Albertos, J.M. , Sánchez, J.L. (eds) (2014) Geografía de la crisis económica en España, València: Publicacions de la Universitat de València.

Alesina, A. , Ardagna, S. (2009) "Large changes in fiscal policy: taxes versus spending", Working Paper 15438. www.nber.org/papers/w15438.

Ali, T. (1999) "Springtime for NATO", New Left Review, 234: pp. 62-75.

Amin, A. (2003) "Industrial districts", in: Barnes, T.J. , Sheppard, E. (eds) A Companion to Economic Geography, Blackwell: Oxford, pp. 149-168.

Amin, A. , Thrift, N. (2005) "What's left? Just the future", Antipode, 37(2): 220-238.

Ancelovici, M. , Dufour, P. , Héloïse, N. (eds) (2016) Street Politics in the Age of Austerity. From the Indignados to Occupy, Amsterdam: Amsterdam University Press.

Andreotti, A. , Mingione, E. (2014) "Local welfare systems in Europe and the economic crisis", European Urban and Regional Studies, 23(3): 231-251.

Anthias, F. , Lazaridis, G. (2000) "Introduction: women on the move in southern Europe", in: Anthias, F. , Lazaridis, G. (eds) Gender and Migration in Southern Europe, Oxford: Berg, pp. 1-14.

ARMAL (Agenzia Regional Marche Lavoro) . (2003) Economia e Territorio. II distretto calzaturiero fermano-maceratese, Ancona.

Armiero, M. , D'Alisa, G. (2012) "Rights of resistance: the garbage struggles for environmental justice in Campania, Italy", Capitalism Nature Socialism, 23(4): 52-68.

Arrighi, G. (ed) (1985) Semiperipheral Development. The Politics of Southern Europe in the Twentieth Century, London: Sage.

Arrighi, G. (1990) "The Developmentalist illusion: a reconceptualization of the semiperiphery", in: Martin, W.G. (ed) Semiperiheral States in the World Economy, Westport, CT: Greenwood Press, pp. 11-42.

Arrighi, G. (1994) The Long Twentieth Century: Money, Power and the Origins of Our Times, London: Verso.

Asheim, B. (1996) "Industrial districts as 'learning regions': a condition for prosperity?", European Planning Studies, (4)4: 379-400.

Athanasiou, A. (2012) The Crisis as "a State of Exception". Critiques and Resistance, Athens: Savalas (in Greek).

Aziz, J. (2015) "The trouble with ordoliberalism", www.pieria.co.uk/articles/the_trouble_with_ordoliberalism

Bagnasco, A. (1977) Tre Italie. La problematica territoriale dello sviluppo italiano, Bologna: il Mulino.

Balabanidis, D. , Patatouka, E. , Siatitsa, D. (2013) "The right to housing during the crisis in Greece", Geographies, 22: 31-42 (in Greek).

Baldwin-Edwards, M. , Arango, J. (eds) (1999) Immigrants and the Informal Economy in Southern Europe, London: Franc Cass.

Barro, R. , Sala-i-Martin, X. (1995) Economic Growth, New York: Mcgraw Hill.

Baumgarten, Br . (2013) "Geração à Rassa and beyond: mobilisations in Portugal after 12 March 2011", Current Sociology, 61(4): 457-473.

Becattini, G. , Bellandi, M. , Dei Ottati , G., Sforzi, F. (eds) (2003) From Industrial Districts to Local Development, Cheltenham: E. Elgar.

Bellina, B. (2013) "Germany in times of crisis: passive revolution, struggle over hegemony and new nationalism", Geografiska Annaler, 95(3): 275-285. 
Bellofiore, R. (2013) "Two or three things I know about her: Europe in the global crisis and heterodox economics", Cambridge Journal of Economics, 37: 497-512.

Belso-Martínez, J.A. (2010) "International outsourcing and partner location in the Spanish footwear sector: and analysis based in industrial district SMEs", European Urban and Regional Studies, 17(1): 65-82.

Benach, N. (2015) "Contested discourses of austerity in the urban margins (a vision from Barcelona)", in: Echardt, F. , Ruiz-Sánchez, J. (eds) City of Crisis. The Multiple Contestation of Southern European Cities, Bielefeld: Transcript Verlag, pp. 31-49, 71-85.

Beramendi, P. (2012) The Political Geography of Inequality: Regions and Redistribution, Cambridge: Cambridge University Press.

Bergfeld, M. (2014) Portugal, 40 years after the Revolution 1974-2014,

http://mdbergfeld.com/2014/04/portugal-40-years-after-the-revolution-ebook/.

Bertoncin, M. , Marini, D. , Pase, A. (2009) Frontiere mobili: delocalizzazione e internazionalizzazione dei territori produttivi veneti, Venezia: Marsilio.

Bianchi, P. , Bellini, N. (1991) "Public policies for local network of innovations", Research Policy, 12: 3, 487-497.

Blim, M. (1989) "Prima e dopo lo sviluppo. Monte San Giusto dall'Unità ad oggi", in: Anselmi, S. (ed) L'industria calzaturiera marchigiana. Dalla manifattura alla fabrica, Fermo, pp. 38-49.

Blim, M. (1990) Made in Italy: Small Scale Industrialization and Its Consequences, New York:

Preager.

Boschma, R.A. (2004) "The competitiveness of regions from an evolutionary perspective", Regional Studies, 38: 993-1006.

Boschma, R.A. , Frenken, K. (2006) "Why is economic geography not an evolutionary science? Towards an evolutionary economic geography", Journal of Economic Geography, 6: 273-302.

Bosi, L. , Zamponi, L. (2015) "Direct social actions and economic crises: the relationship between forms of action and socio-economic context in Italy", PArtecipazione e COnflitto, 8(2): 367-391.

Bourdieu, P. (1980) "Le capital social", Actes de la Recherche en Sciences Social, 3(2-3): 123-134.

Bourdieu, P. (1990) The Logic of Practice, Stanford: Stanford University Press.

Boyer, R. (2000) "Is a finance-led growth regime a viable alternative to Fordism? A preliminary analysis", Economy and Society, 29(1): 111-145.

Braudel, F. (1966) La Méditerranée et le Monde Méditerranéan à l' Epoque de Philippe II, vol. 1 et 2, Paris: Librairie A. Colin.

Brenner, N. (1997) "Global, fragmented, hierarchical: Henri Lefebvre's geographies of globalization", Public Culture, 10: 137-169.

Bruff, I. (2011) "What about the elephant in the room? Varieties of capitalism, varieties in capitalism", New Political Economy, 16(4): 481-500.

Burroni, L. (2016) Capitalismi a confronto. Istituzioni e regolazione dell'economia nei paesi europei, Bologna: il Mulino.

Buzzati, St. , Pasquato, Ch . (2009) "Tra successo e fallimento. La sfaccettature della territorialità nel distretto dello SportSystem di Montebelluna", in: Bertoncin, M. , Marini, D. , Pase, A. (eds) Frontiere Mobili. Delocalizzazione e internationalizzazione dei territori produttivi veneti, Venezia: Marcilio, pp. 47-70.

Cabot, H. (2016) "Contagious" solidarity: reconfiguring care and citizenship in Greece's social clinics", Social Anthropology, 24(2): 152-166.

Cadelli, M. (2016) "Le néoliberalism est un fascism", Le Soir, 3 March 2016.

Calvário, R. , Velegrakis, G. , Kaika, M. (2016) "The political ecology of austerity: an analysis of socio-environmental conflict under crisis in Greece", Capitalism Nature Socialism, doi:10.1080/10455752.2016.1260147.

Cánovas, A.P. , Riquelme Perea, J. (2007) "La condición inmigrante de los nuevos trabajadores rurales", Revista Española de Estudios Agrosociales y Pesqueros, 211: 189-238.

Capecchi, V. , Pesce, A. (1983) "Se la diversità è un valore", Inchiesta, 13: 59-60.

Carvalho, L. (2017) "Life after the squares: reflections on the consequences of the occupy movements" (intervention on Rossio), Social Movements Studies, 16(1): 119-151.

Castells, M. (1983) The City and the Grassroots. A Cross-Cultural Theory of Urban Social Movements, London: Arnold. 
Castells, M. (2016) Networks of Outrage and Hope: Social Movements in the Internet Age, London: Polity.

Castro, M. , Garcia, B. , Vatavali, F. , Zifou, M. (2013) "Ultra-neoliberal urban development in Spain and Greece. The case of Port Vell in Barcelona and Hellinikon Airport in Athens", Geographies, 22: 14-29 (in Greek).

Cecchi, E. , Seassaro, A. , Simonelli, G. , Sorlini, C. (1978) Centri Sociali autogestiti e circoli giovanili, Milano: Fetrinelli.

Cervellati, P. , Scannavini, R. (1973) Bologna. Politica e metodologia del restauro nei centri storici, Bologna: II Mulino.

Charnock, G. , Purcell, Th. , Ribera-Fumaz, R. (2014) The Limits to Capital in Spain: Crisis and Revolt in the European South, London: Palgrave MacMillan.

Chomsky, N. (1999) The New Military Humanism: Lesson from Kosovo, London: Pluto Press. Clark, G. (2014) "The geography of the Euro Crisis: the ECB, its institutional form, functions and performance". Paper presented at AAG, Florida, April 2014 (available from the author).

Clark, J. , Jones, A. (2008) "The spatialities of Europeanisation: territory, government and power in Europe", Transactions of the Institute of British Geographers, NS 33, 300-318c.

Cómo cocinar una revolutión no violenta, http://takethesquare.net/es/2011/08/18/como-cocinaruna-revolution-no-violenta/.

Compaña Quién Debe a Quién . (ed) (2011) Vivir en deudocracia. Iban un portugués, un irlandés, un griego y un español....Barcelona: Icaria.

Conill, J. , Castells, M. , Cardenas, A. , Servon, L. (2012) "Beyond the crisis: alternative economic practices in Catalonia", in: Castells M. , Caraçao, J. , Cardoso, G. (eds) After-Math. The Culture of Economic Crises, Oxford: Oxford University Press, pp. 211-248.

Cooke, P . Morgan, K . (1998) The Associational Economy: Firms, Regions and Innovation, Oxford: Oxford University Press.

Coq-Huelva, D. (2013) "Urbanisation and financialisation in the context of a rescaling state: the case of Spain", Antipode, 45(5): 1213-1231.

Credit Suisse . (2016) Global Wealth Data Book, www.credit-suisse.com/articles/2016/theglobal-wealth-report-2016.ht

Crestanello, P. (1999) L' industria veneta di abbigliamento: internazionalizzazione produttiva e piccole imprese di sub-fornitura, Milano: F.Angeli.

Croce, B. (1925/1970 transl) History of the Kingdom of Naples, Chicago: University of Chicago Press.

Cutrini, E. (2011) "Moving Eastwards while remaining embedded: the case of the Marche footwear district, Italy", European Planning Studies, 19(6): 991-1014.

D' Alisa, G. , Forno, F. , Maurano, S. (2015) "Grassroots (economic) activism in times of crisis", PArtecipazione e COnflitto, 8(2): 328-342.

Davis, M. (2011) "Spring confronts Winder", New Left Review, 72: 5-15.

De Cesaris, W. (2009) "The speculative real-estate bubble and the securitisation scandal in Italy", www.transform-network.net/yearbook/journal-052009/9.

Del Monte, A. , Giannola, A. (1978) II Mezzogiorno nell' economia italiana, Bologna: II Mulino.

Della Porta, D . (2015) Social Movements in Times of Austerity: Bringing Capitalism Back into

Protest Analysis, London: Polity.

Della Porta, D. , Mattoni, A. (eds) (2014) Spreading Protest. Social Movements in Times of

Crisis, Colchester: ECPR Press.

Diani, M. , Kousis, A. (2014) "The duality of claims and events: the Greek campaign against the Troika's Memoranda and austerity, 2010-2012", Mobilization: An International Quarterly, 19(4): 387-404.

Dicken, P. (2015) Global Shift. Mapping the Changing Contours of the World Economy, London: Sage (seventh edition).

Dijstelbloem, H. , Meijer, A. (eds) (2011) Migration and the New Technological Borders of Europe, London: Palgrave MacMillan.

Dinoto, I. (2013) "Housing crisis in Italy", Geographies, 22: 43-44.

Dorling, D. (2010) Injustice. Why Social Inequality Persists, Bristol: The Polity Press.

Douzinas, C. (2013) "Athens rising”, European Urban and Regional Studies, 20(1): 134-138.

Dunford, M. , Dunford, R. , Barbu, M. , Weidong, L. (2013) "Globalisation, cost competitiveness and international trade: the evolution of the Italian textile and clothing industries and the growth of trade with China", European Urban and Regional Studies, 21: 1-25. 
Dunford, M. , Yeung, G. (2009) "Port-Industrial Complexes", in: Kitchen, R. , Thrift, N. (eds) International Encyclopedia of Human Geography, Regional Development Section, Elsevier, www.elsevier.com/HUGY/Dunford_Yeung.

ECB (2015) Real estate markets and macroprudential policy in Europe, ECB Working Paper 1796, May 2015.

Eco, U. (1992) "Qual è il costo di un impero fallito?", L' Espresso, 6 September.

Eizaguirre, S. , Pradel, M. , Garcia, M. (2017) "Citizenship practices and democratic governance: "Barcelona en Comú" as un urban citizenship confluence promoting a new policy agenda", Citizenship Studies, 21(4): 425-439.

Ekers, M. , Hart, G. , Kipfer, St. , Loftus, A. (eds) (2013) Gramsci. Space, Nature, Politics, Chichester: Wiley-Blackwell.

Eurispes (2001) Rapporto Italia, Roma: Ufficio Stampa Eurispes.

Europe 2020 (2010) A European Strategy for Smart, Sustainable and Inclusive Growth, Brussels, www.ec.europa.eu/eu2020/pdf/COMPLETE

Fazi, Th . (2017) "Public debt in the Eurozone: a political problem", speech given at the conference "How to Deal with Public Debt?-Lesson Learned and Policies Ahead", 7 March , GUE/NGL, European Parliament, http://www.socialeurope.eu/2017/03/public-debt-eurozonepolitical-problem-financial-one/.

Featherstone, D. (2012) Solidarity: Hidden Histories and Geographies of Internationalism, London: Zed Books.

Featherstone, D. (2013) "Gramsci in action": space, politics and the making of solidarities", in: Ekers, M. , Hart, G. , Kipfer, St. , Loftus, A. (eds) Gramsci. Space, Nature, Politics, Chichester: Wiley-Blackwell, pp. 65-82.

Fernández-Savater, A. , Flesher Fominaya, C . (ed) (2017) "Life after the squares: reflections on the consequences of the occupy movements", Social Movement Studies, 16(1): 119-151 (with contributions by Carvalho, L. , Hoda Elsadda, G. , El-Tamami, W. , Horrillo, P. , Nanclares, S ., Stavrides, S.).

Flassbeck, H. (2010) "Avis de tempête sur l'Union monétaire européenne", Le Monde, 5 March 2010.

Fondazione Nordest . (2003) La de-localizzazione produtiva all estero nel settore moda: il Caso Vicenza, Venezia (mimeo).

Foster, J.B. (2007) "The financialization of capitalism", Monthly Review, 58(11).

Fraser, N. (1995) "From redistribution to recognition? Dilemmas of justice in a 'post-socialist' age", New Left Review, 212: 68-93.

Fraser, N. (2006) "Reframing justice in a globalizing world", New Left Review, 36, Nov-Dec: 69-88.

Fraser, N. (2008) Scales of Justice. Reimagining Political Space in a Globalizing World, Cambridge: Polity.

Fraser, N. (2013) “A triple movement?", New Left Review, 81, May-June: 119-132.

Fraser, N. (2016) "Crises of care: the contradictions of social reproduction in the era of financial capitalism", The Annual Nicos Poulantzas Lecture, Nicos Poulantzas Institute, Athens, 7 December 16. http://poulantzas.gr/rethinking-greece-nancy-fraser/.

Fujita, M. , Krugman, P. (2004) "The new economic geography: past, present and future", Papers in Regional Science, 83: 139-164.

Galeano, E. (1995) Walking Words, New York: Gorton \& Company, (translated by Mark Fried). Galeano, E. (2004) "Interview", in: Barsamian, D. (ed) Louder than Bombs: Interviews from the Progressive Magazine, New York: South End Press, p. 146.

Gambarotto, F. , Solari, St . (2015) "The peripheralization of Southern European Capitalism with the EMU", www.siecon.org/online/wp-content/uploads/2013/09/Gambarotto-Solari.

García, M. (2010) "The breakdown of the Spanish urban growth model: social and territorial effects of the global crisis", International Journal of Urban and Regional Research, 34(4): 967-980.

Garofoli, G. (1983) Industrializazione diffuza in Lombardia, IPER/F. Milano: Angeli.

Gialis, S. , Herrod, A. (2014) "Of steel and strawberries: Greek workers struggle against informal and flexible working arrangements during the crisis", Geoforum, 57: 138-149.

Gialis, St. , Leontidou, L. (2016) "Antinomies of flexibilization and atypical employment in Mediterranean Europe: Greek, Italian and Spanish regions during the crisis", European Urban and Regional Studies, 23(4): 716-733. 
Gibelli, M.-C. (2015) "Urban crisis or urban decay? Italian cities facing the effects of a long wave towards privatization of urban policies and planning", in: Echardt, F. , Ruiz-Sánchez, J. (eds) City of Crisis. The Multiple Contestation of Southern European Cities, Bielefeld: Transcript Verlag, pp. 89-108.

Giner, S. , Sevilla, E. (1984) "Spain: from corporatism to corporatism", in: Williams, A. (ed) Southern Europe Transformed, London: Harper and Raw, pp. 113-144.

Golemis, H. (2010) "Can PIGS Fly?" Transform! European Journal for Alternative Thinking and Political Dialogue, 6: 129-136.

Gonick, S. (2016) "Indignation and inclusion: activism, difference, and emergent urban politics in postcrash Madrid", Environment and Planning D: Society and Space, 34(2): 209-226.

Gonzáles-Diaz, B. , Gandoy, R. (2005) "Understanding offshoring: has Spain been an offshoring location in the 1990s?" www.ub.edu/jei/papers/GONZALEZ-GANDOY.pdf.

Grabher, G. (2009) "Yet another turn? The evolutionary project in economic geography", Economic Geography, 85(2): 119-127.

Grazioli, M. (2017) "From citizens to citadins? Rethinking right to the city inside housing squats in Rome, Italy", Citizenship Studies, 21(4): 393-408.

Greber, D. (2011) Debt. The first 5,000 years, New York: Mellvile House Publ.

Gregory, D. (1995) “Imaginative geographies”, Progress in Human Geography, 19: 447-485.

Gregory, D. (2004) The Colonial Present, Oxford: Blackwell.

Guldi, J. , Armitage, D. (2014) The History Manifesto, Cambridge: Cambridge University Press. Hadjimichalis, C. (1987) Uneven Development and Regionalism: State, Territory and Class in Southern Europe, London: Croom Helm.

Hadjimichalis, C. (2006) "The end of third Italy as we knew it?", Antipode, 38(1): 82-106. Hadjimichalis, C. (2010) "The Greek economic crisis and its geography: from R. Kaplan's geographical determinism to uneven geographical development”, Human Geography: A New Radical Journal, 3(3): 89-100.

Hadjimichalis, C. (2011) "Uneven geographical development and socio-spatial justice and solidarity: European regions after the 2009 financial crisis", European Urban and Regional Studies, 48(3): 254-274.

Hadjimichalis, C. (2013) "Luchas urbanas y construcción de redes de solidaridad en Atenas durante la crisis", Urban, NS06: 79-97.

Hadjimichalis, C. (2014) "Crisis and land dispossession in Greece as part of the global 'land fever"', City: Analysis of Urban Trends, Culture, Theory, Policy, Action, 18(4-5): 502-508, doi:10.1080/13604813.2014.939470.

Hadjimichalis, C. (2014) Debt Crisis and Land Dispossession, Athens: KUM Publications (in Greek). See also the German translation: Schuldenkrise and Landraub in Griechenland, Münster: Westfälishe Dampfboot (2016).

Hadjimichalis, C. , Hudson, R. (2004) "Networks, regional development and democratic control", in: Proceedings of Seminars of the Aegean, Naxos 2003, Athens-Thessaloniki, pp. 123-139. Hadjimichalis, C. , Hudson, R. (2007) "Rethinking local and regional development: implications for radical political practice in Europe", European Urban and Regional Studies, 14(2): 99-113. Hadjimichalis, C. , Hudson, R. (2014) "Contemporary crisis across Europe and the crisis of regional development theories", Regional Studies, 48(1): 208-218.

Hadjimichalis, C. , Papamichos, N. (1990) "Local development in Southern Europe: towards a new mythology", Antipode, 22(3): 181-200.

Hadjimichalis, C. , Sadler, D. (eds) (1995) Europe at the Margins. New Mosaics of Inequality, Chichester: Wiley.

Hadjimichalis, C. , Vaiou, D. (1990) "Whose flexibility? The politics of informalisation in Southern Europe", Capital and Class, 42, Winter: 79-106.

Hadjimichalis, C. , Vaiou, D. (2004) "Local" illustrations for "International" geographical theory", in: Simonsen, K. , Bœrenholdt, J.O. (eds) Space Odysseys, Aldershot: Ashgate, pp. 171-182. Harrison, B. (1994) "The Italian industrial districts and the crisis of the cooperative form: part I", EPS, vol. 2:1, pp. 3-22 and part II, EPS, vol. 2:2, pp. 159-174.

Harvey, D. (1973) Social Justice and the City, Baltimore: Johns Hopkins University Press.

Harvey, D. (1982) The Limits to Capital, Oxford: B. Blackwell.

Harvey, D. (2003) The New Imperialism, Oxford: Oxford University Press.

Harvey, D. (2009) "The right to the Just City", in: Marcuse, P. , Connolly, J., Novy, J. , Olivo, I. (eds) Searching for the Just City, London: Routledge, pp. 40-51. 
Harvey, D. (2010) The Enigma of Capital, London: Profile Books.

Harvey, D. (2011) "Crises, geographic disruptions and the uneven development of political responses", Economic Geography, 87(1): 1-22.

Harvey, D. (2012) Rebel Cities: From the Right to the City to the Urban Revolution, London: Verso.

Harvey, D. (2014) Seventeen Contradictions and the End of Capitalism, London: Profile Books. Hay, C. (1999) "Crisis and the structural transformation of the state: interrogating the process of change", British Journal of Politics and International Relations, 1(3): 317-344.

Healey, P. (1997) Collaborative Planning: Shaping Place in Fragmented Societies, London: Macmillan.

Hodgson, G.M. (2005) "Generalizing Darwinism to social evolution: some early attempts", Journal of Economic Issues, 39: 899-914.

Horrilo, P. , Nanclares, S. (2017) "Life after the squares: reflections on the consequences of the occupy movements" (intervention on Puerta del Sol), Social Movements Studies, 16(1): 119-151.

Hudson, R. (1999) "The learning economy, the learning firm and the learning region: a sympathetic critique of the limits to learning", European Urban and Regional Studies, 6(1): 59-72.

Hudson, R. (2001) "Regional development, flows of value and Governance in an Enlarged Europe", Regional Regeneration and Development Studies, University of Durham (mimeo). Hudson, R. (2005) Economic Geographies-Circuits, Flows and Spaces, London: Sage. Hudson, R. (2007) "Regions and regional uneven development forever? Some reflective comments upon theory and practice", Regional Studies, 14(9): 1149-1160.

Hudson, M. (2010) "The transition from industrial capitalism to a financialized bubble economy", Working Paper 627, Levy Economics Institute, www.levyinstutute.org/pubs/wp_627.

Hudson, R. (2017) "Facing forwards, looking backwards: coming to terms with continuing uneven development in Europe", European Urban and Regional Studies, 24(2): 138-141. Hudson, R. , Lewis, J. (1985) Uneven Development in Southern Europe, London: Methuen. II Sole 24ore (2002) "Carpi un distretto all cinese", 19 July 2002.

INE/GSEE (2010) The Greek Economy and Employment, Annual Report, Athens (in Greek): Greek Labour Institute.

IOBE (2015) The Importance, Obstacles and Future of the Construction Sector in Greece, Athens (in Greek): IOBE.

Jabko, N. (2010) "The hidden face of the euro", Journal of European Public Policy, 17(3): 318-334.

Jessop, B. (2005a) "Gramsci as a spatial theorist", Critical Review of International Social and Political Philosophy, 8(4): 561-574.

Jessop, B. (2005b) "The political economy of scale and European governance", Tijdschrift voor Economische en Sociale Geographie, 96(2): 225-230.

Jessop, B. (2011) "Rethinking the diversity and variability of capitalism. On variegated capitalism in the world market", in: Lane, C. , Wood, G. (eds) Capitalist Diversity and Diversity within Capitalism, London: Routledge, pp. 211-237.

Kaejane, G. (2011) "Seven key words for the Spanish experience, Puerta del Sol, M15", www.edu-factory.org/wp/spanishrevolution (accessed 15 December 2012 ).

Kaika, M. (2012) "The economic crisis seen from the everyday: Europe's nouveau poor and the global affective implications of a "local" debt crisis", City, 16(4): 422-429.

Kaika, M. , Karaliotas, L. (2016) "The spatialisation of democratic politics: insights from the Indignant Squares", European Urban and Regional Studies, 22(4): 556-570.

Kalogeresis, A. , Labrianidis, L. (2008) "Delocalization and development in Europe: conceptual issues and empirical findings", in Labrianidis, L. (ed) The Moving Frontier. The Changing Geography of Production in Labour-Intensive Industries, Aldershot: Ashgate, pp. 23-58. Kaplan, R. (1994) Balkan Ghosts: A Journey through History, New York: Vintage Books. Kaplan, R. (2009) "The revenge of geography", Foreign Policy, 179: 96-105.

Kaplan, R. (2010) "For Greece's economy, geography was destiny”, The New York Times, 25 April 2010.

Karamesini, M. (2013) "Structural crisis and adjustment in Greece: social regression and the challenge to gender equality", in: Karamesini, M. , Rubery, J. (eds) The Economic Crisis and the Future of Gender Equality, London: Routledge, pp. 165-185. 
Karamesini, M. , Rubery, J. (eds) (2013) The Economic Crisis and the Future of Gender Equality, London: Routledge.

Kearns, G. (2009) "Mackinder Redux", Human Geography, 2(2): 44-48.

King, R. (2000) "Southern Europe in the changing global map of migration", in: King, R. , Lazaridis, G. , Tsardanidis, Ch . (eds) Eldorado or Fortress? Migration in Southern Europe, London: MacMillan, pp. 1-26.

Kousis, M. (2016) "The spatial dimension of the Greek protest campaign against the Troika's Memoranda and austerity, 2010-1013", in: Ancelovici, M. , Dufour, P. , Nez, H. (eds) Street Politics in the Age of Austerity, Amsterdam: Amsterdam University Press, pp. 147-174.

Kousis, M. , Kalogeraki, St., Papadaki, M. , Loukakis, A. , Velonaki, M. (2016, forthcoming) "Alternative forms of resilience in Greece", Forschungsjournal Soziale Bewegungen, 29(1): 50-61 (in German).

Koutrolikou, P. , Spanou, D. (2013) "The local as an arena for emerging mobilizations and solidarity in the context of the current crisis", Geographies, 22: 52-66 (in Greek).

Krugman, P. (1991) Geography and Trade, Cambridge, MA: MIT Press.

Krugman, P. (1993) "Lessons of Massachusetts for EMU", in: Torres, F. and Giavazzi, F. (eds) Adjustment and Growth in the European Monetary Union, London: CEPR, Cambridge University Press.

Krugman, P. (2010) "The Euro Trap", The New York Times, 9 May 2010.

L'Ordine Nuovo , 1919-1920, (1995) Turin: Einaudi.

Labrianidis, L. (ed) (2008) The Moving Frontier. The Changing Geography of Production in Labour-Intensive Industries, Aldershot: Ashgate.

Labrianidis L. (2011) Investing in leaving: The Greek case of international migration of professionals in the globalization era. Athens: Kritiki (in Greek).

Labrianidis, L. , Vogiatsis, N. (2013) "The mutually reinforcing relations between international migration of highly educated labour force and economic crisis: the case of Greece", Southeast European and Black Sea Studies, 13(4): 525-551.

Lafazani, O. (2004) "Grassroots migrant organizations and Antiracist Initiatives in Greece: difficult encounters, interesting connections". Paper presented in the International Symposium "Transnational Europe I - Migration across southern/eastern borders", University of Crete, Rethymno.

Lafazani, O. (2012) "The Border between Theory and Activism", An International E-Journal for Critical Geographies, 11(2): 189-193.

Lafazani, O. (2014) Geographies of transnational migration, PhD Thesis, Department of Geography, Harokopio University, Athens (in Greek).

Lanziani, A. (ed) (2003) Metamorfosi urbane. I luoghi dell'immigrazione, Pescara: Sala Editori. Lapavitsas, C. (2013) Profiting without Producing. How Finance Exploits Us All, London: Verso. Lapavitsas, C. , Kaltenbrunner, A. , Labrinidis, G. , Lindo, D. , Meadway, J. , Michell, J. ,

Painceira, J.P. , Pires, E. , Powell, J. , Stenfors, A. , Teles, N. , Vatikiotis, L. (2012) Crisis in the Eurozone, London: Verso.

Lazzarato, M. (2012) The Making of the Indebted Man. An Essay on the Neoliberal Condition, Los Angeles: Semiotext(e).

Lefebvre, H. (1973) La Survive du Capitalisme: la reproduction des rapports de production, Paris: Antropos (translated in Greek 1975 and in English 1976).

Lefebvre, H. (1974) La production de l' espace, Paris: Anthropos.

Lefebvre, H. (1976) De l' Etat (4 volumes), Paris : Union générale d'éditions

Leonardi, R. (2006) "Cohesion in the European Union", Regional Studies, 40(2): 155-166.

Leontidou, L. (2012) "Athens in the Mediterranean 'movements of the piazzas'. Spontaneity in material and virtual public spaces", City, 16(3): 299-312.

Levi, C. (1990) Cristo se è fermato a Eboli, Torino: Einaudi.

LIVEWHAT (2016) Living with Hard Times. How Citizens React to Economic Crises and Their Social and Political Consequences, EU 7th Framework Programme (613237) in:

http://www.livewhat.unige.ch/.

López Hernández, I. , Rodríguez López, E. (2010) Fin de ciclo: financiarización, territorio y sociedad de propietarios en la onda larga del capitalismo hispano (1959-2010), Madrid: Traficantes de Sueños.

Loureiro de Matos, F. , Miramontes Carballada, A. , Sa Marques, T. , Ribeiro, D. (2015)

"Housing in a time of crisis: Portugal and Spain an overview", 
www.enhr2015.com/images/Southern_European.

Lovering, J. (1999) "Theory led by policy: the inadequacies of the new regionalism", International Journal of Urban and Regional Research, 23(2): 379-395.

MacKinnon, D. , Cumbers, A. , Pike A. , Birch K. , MacMaster R. (2009) "Evolution in economic geography: institutions, political economy and adaptation, Economic Geography, 85(2):

804-829.

Magnifico, G. (1973) European Monetary Unification, London: Macmillan.

Mantanika, R. , Kouki, H. (2011) "The spatiality of a social struggle in Greece at the time of the IMF: reflections on the 2011 mass migrant hunger strike in Athens", City, 15(3-4): 482-490.

Marques, P. (2015) "Why did the Portuguese economy stop converging with the OECD? Institutions, politics and innovation", Journal of Economic Geography, 15(5): 1009-1031. Marsden, T. , Banks, J. , Bristow, G. (2000) "Food supply chains approaches: exploring their role in rural development", Sociologia Ruralis, 40(4): 424-438.

Mart, M. (2013) "Housing bubble, crisis and social struggle in Spain", Geographies, 22: 45-48.

Martin, R. (2000) "EMU versus the Regions? Regional convergence and divergence in Euroland", Working Paper No. 179, ESRL Center for Business Research, University of Cambridge.

Martinez-Veiga, U. (2001) El Ejido. Discriminación, exclusión y racismo, Madrid: Los Libros de la Catarata.

Massey, D. (1999) Power-geometries and the Politics of Space-Time, Hettner-Lectures 2, Heidelberg: University of Heidelberg.

Massey, D. (2004) "Geographies of responsibility”, Geografiska Annaler, 86 B(1): 5-18.

Massey, D. (2006) "Space, Time and Political Responsibility in the Midst of Global Inequality", Erdkunde - Archive for Scientific Geography (Department of Geography, University of Bonn, Germany) 60(2): 93-106.

Massey, D. (2007) World City, London: Polity.

Massey, D. (2012) Radical Spatiality and the Question of Democracy, Invited Talk, Ceremony for Doreen Massey's Honorary Doctorate at the Geography Department, Harokopio University, Athens, Greece, Athens: Harokopio University.

Massey, D. (2015) "Vocabularies of the economy", in Hall, St. , Massey, D. , Rustin, M. (eds) After Neoliberalism? The Kilburn Manifesto, London: Soundings, pp. 24-36.

Massey, D. , Hall, S. (2010) "Interpreting the crisis", Soundings,

www.fags.org/periodicals/201004.

Mayayo, G. (2007) "The Spanish mortgage market and the American subprime crisis" www.ahe.es/bocms/images (accessed September 2013 ).

Mayer, M. (2013) "Against and beyond the crisis: the role of urban social movements", Geographies, 22: 67-72.

McLeod, G. (2001) "New regionalism reconsidered: globalization and the remaking of political economic space", International Journal of Urban and Regional Research, 25(4): 804-829.

Medelfart, K.-H. , Overman, H. , Venables, A. (2003) "Monetary union and the economic geography of Europe", Journal of Common Market Studies, 41(5): 847-868.

Merrifield, A. , Swyngedouw, E. (eds) (1996) The Urbanization of Injustice, London: Lawrence \& Wishart.

Mezzadra, S. , Neilson, B. (2013) The Border as a Method or the Multiplication of Labor, Durham and London: Duke University Press.

Miguélez, F. , Recio, A. (2010) "The uncertain path from the Mediterranean welfare model in Spain", in: Anxo, D. , Bosh, G. , Rubery, J. (eds) The Welfare State and Life Transitions. A European Perspective, Cheltenham: Edward Elgar, pp. 284-308.

Mingione, E. (1991) Fragmented Societies. A Sociology of Economic Life beyond the Market Paradigm, Oxford: Blackwell.

Mingione, E. (1995) "Labour market segmentation and informal work in Southern Europe", European Urban and Regional Studies, 2(2): 121-143.

Mingione, E. (1998a) "The social and historical construction of the models of industrial development", in Space, Inequality and Difference. From "Radical" to "Cultural" Formulations? Milos, 1996, Seminars of the Aegean, Atene, 1998, pp. 82-106.

Mingione, E. (1998b) Sociologia della vita economica, Roma: Carocci.

Mingione, E. (2000) "Modello Sud Europeo di welfare. Forme di povertà e politiche contro l'esclusione sociale" in Sociologia e Politiche Sociali ( P. Donati ed) a.3, n.1, pp. 87-112. 
Mingione, E. (2009) "Family, welfare and districts: the local impact of the new migrants in Italy", European Urban and Regional Studies, 16(3): 225-230.

Morgan, K. (1977) "The learning region: institutions, innovation and regional renewal", Regional Studies, 31(5): 491-503.

Morrissey, J. (2009) "Lessons in American geopolitik: Kaplan and the return of spatial absolutism", Human Geography, 2(2): 37-39.

Nardone, C. (1971) II pensiero di Gramsci, Bari: De Donato.

Nesi, E. (2010) Storia della mia gente, Milano: Bombiani.

Nicevero, A. (1898) L' Italia barbara contemporanea, Milano/Palermo.

Nurra, M. , Azzu, M. (2011) Asinara Revolution, Milano: Bompiani.

Observatorio Metropolitano . (2011a) Crisis y revolución en Europa. People of Europe, rise up!

Madrid: Traficantes de Sueños. www.rebelion.org/docs/138745.pdf. IN ENGLISH.

Observatorio Metropolitano . (2011b) La crisis que viene. Algunas notas para afrontar esta

década. Madrid: Traficantes de Sueños.

www.traficantes.net/sites/default/files/pdfs/La\%20crisis\%20que\%20viene-

Traficantes\%20de\%20Sueños.pdf.

Observatorio Metropolitano . (ed) (2013) Paisajes devastados. Después del ciclo inmobiliario:

impactos regionales y urbanos de la crisis, Madrid: Traficantes de Sueños.

OECD (2003) Annual Report, https://oecd.org/about/2506789.

OECD . (2010) Labour Productivity, https://data.oecd.org/lprdty/gdp-per-hour-worked.htm.

OECD . (2013) International Migration Outlook, Paris: OECD.

Paci, M. (1972) Mercato del lavoro e classi sociali in Italia, Bologna: II Mulino.

Painter, J. (2003) "Towards a post-disciplinary political geography", Political Geography, 22: 637-639.

Papadopoulou, E. , Sakellaridis, G. (eds) (2012) The Political Economy of Public Debt and Austerity in the EU, Brussels: Transform!.

Papataxiarchis, E. (2016a) "Being 'there': at the front line of the 'European refugee crisis'", Part 1, Anthropology Today, 32(2): 5-9.

Papataxiarchis, E. (2016b) "Being 'there': at the front line of the 'European refugee crisis'”, Part 2, Anthropology Today, 32(3): 3-7.

Papataxiarchis, E. (2016c) "Unwrapping solidarity? Society reborn in austerity", Social

Anthropology, 24(2): 205-210.

Papic, M. , Reinfrank, R. , Zeihan, P. (2010) "Insights economics: Greece and Germany to exit the Eurozone", Straftor Documents, http://www.marketoracle.co.uk/.

Peck, J. (2012) “Austerity urbanism”, City, 16(6): 626-655, doi:10.1080/13604813.2012.734071.

Peck, J. , Theodore, N. , Brenner, N. (2010) "Postneoliberalism and its malcontents", Antipode, 41(supplement 1): 94-116.

Peet, R. (1985) "The social origins of environmental determinism", Annals of the Association of American Geographers, 75(3): 309-333.

Perrons, D. (2004) Globalization and Social Change, London: Routledge.

Perrons, D. (2010) Why socio-economic inequalities increase? Facts and policy responses in Europe, Directorate-General for Research 2010 Socio-economic Sciences and Humanities EUR 24471 EN.

Perrons, D. (2012a) “'Global' financial crisis, earnings inequalities and gender: towards a more sustainable model of development", Comparative Sociology, 11: 202-226.

Perrons, D. (2012b) "Regional performance and inequality: linking economic and social development through a capabilities approach", Cambridge Journal of Regions, 5: 15-29.

Petmesidou, M. , Pavolini, E. , Guillén, A.M. (2015) "South European healthcare systems under harsh austerity: a progress-regression mix?", in: Petmesidou, M. , Guillén, A.M. (eds) Economic Crisis and Austerity in Southern Europe, London: Routledge, pp. 37-58.

Pickles, J. , Smith, A. (2011) "Delocalization and the persistence in the European clothing industry", Regional Studies, 45: 167-185.

Pickles, J. , Smith, A. (2015) Articulations of Capital: Global Production Networks and Regional Transformations, Chichester: Wiley.

Pike, A. (2007) "Whither Regional Studies?" Editorial, Regional Studies, 41(9): 1143-1148.

Pike, A. , Rodriguez-Pose, A. , Tomaney, J. (2007) "What kind of local and regional

development and for whom?" Regional Studies, 41(9): 1253-1269. 
Pivetti, M. (1998) "Monetary versus political unification in Europe", Review of Political Economy, 10(1): 5-25.

Plank, L. , Staritz, C. (2015) "Global competition, institutional context and regional production networks: up-and downgrading experiences in Romania's apparel industry", Cambridge Journal of Regions, Economy and Society, doi:10.1093/cjires/rsv014.

Poço, M. , Lopez, C. , Silva, A. (2015) "Perceptions of tax evasion and tax fraud in Portugal", www.gestaodefraude.eu.

Politi, J. (2016) Demonizing and Idealizing the South. A Literary Voyage in Space and Time, Nicos Poulantzas Institute, Athens: Nisos Publ. (in Greek).

Portaliou, E. (2007) "Anti-global movements reclaim the city", City, 11(2): 165-175.

Portaliou, E. (2008) "Urban movements in Athens. Notes for postgraduate studies, NTUA", www.courses.arch.ntua.gr/121473.html (accessed 30 February 2013 ).

Porter, M. (1998) "Clusters and the new economics of competition", Harvard Business Review, 76(6): 77-90.

Poulantzas, N. , Althuser, L. , Balibar, E. (1980) Debating the State, Athens: Agonas (in Greek). Pugliese, E. (1985) "Farm workers in Italy: agricultural working class, landless peasants or clients of the welfare state?", in: Hudson, R. , Lewis, J . (eds) Uneven Development in Southern Europe, London: Methuen, pp. 123-139.

Pugliese, E. (1995) "New international migrations and the "European Fortress", in: Hadjimichalis, C. , Sadler, D. (eds) Europe at the Margins. New Mosaics of Inequality, Chichester: J. Wiley, pp. 51-68.

Pugliese, E. (2002) L' Italia tra migrazioni internationali e migrazioni interne, Bologna: il Mulino. Putnam, R. (1993) Making Democracy Work, Princeton: Princeton University Press.

Rakopoulos, Th . (2015) "Solidarity's tensions: informality, sociality and the Greek crisis", Social Analysis, 59(3): 85-104.

Recio, A. (2010) "Capitalismo español: la inevitable crisis de un modelo insostenibile", Revista Economia Crítica, 9: 198-222.

Reyneri, E. (2001) Migrants in irregular employment in the Mediterranean countries of the European Union, International Migration Papers, no 41, ILO, Geneva. www.llo.org/public/english/migrant/research.

Rodrigues, J. , Reis, J. (2012) "The asymmetries of European integration and the crisis of capitalism in Portugal", Competition and Change, 16: 188-205.

Romão, T.G. (2015) Evolution of the Portuguese construction sector, Master Thesis, Tecnico Lisboa.

Rossi, U. (2009) "Growth Poles-Growth Centers", International Encyclopedia of Human Geography, Regional Development Section, Elsevier. www.elsevier.com/HUGY.

Roth, K.H. (2013) Before the Greek Debt Crisis, a Pamphlet, London: Zero Books.

Rozakou, K. (2015) "The Lesvos pass: crisis, humanitarian governance and solidarity", Sychrona Themata, 130-131: 13-16 (in Greek).

Rozakou, K. (2016) "Crafting the volunteer: voluntary association and the reformation of solidarity", Journal of Modern Greek Studies, 34: 78-101.

Said, E. (1979/1996 Greek edition) Orientalism, Athens: Nefeli (in Greek).

Said, E. (2001) "Orientalism reconsidered", in: Reflection on Exile and other Literary and Cultural Essays, New York: Granta books (Greek translation, Athens: Scripta, 2006), pp. 317-342.

Salento, A. (2014) "The neo-liberal experiment in Italy: false promises and social disappointments", CRESC Working Paper Series, Working Paper No. 137, www.cresc.ac.uk. Sayer, A. (2015) Why We Can't Afford the Rich, Bristol: Polity Press.

Schmidt, I. (2010) "European capitalism: varieties of crisis", Alternate Routes - A Journal of Critical Social Research, 22: 71-86.

Schraad-Tischler, D. , Kroll, C. (2014) and (2016) Social Justice in the EU-A cross-national comparison, Bertelsmann Stiftung, Bielefeld. www.bertelsamnn-stiftung.de.

Schultz-Dornburg, J. (2012). Ruinas modernas. Una topografía del lucro. Barcelona: Àmbit. Scott, A. , Storper, M. (1988) "The geographical foundations and social regulation of flexible production complexes", in: Wolch, J. , Dear, M. (eds) The Power of Geography, London: Allen and Unwin, pp. 21-40.

Scroccaro, A. , Sivieri, C. (2009) "Timişoara e l'imprenditoria della calzatura veneta. Dal distretto dello SportSystem di Montebelluna a 'Trevişoara', in: Bertoncin, M. , Marini, D. , Pase, 
A. (eds) Frontiere Mobili. Delocalizzazione e internationalizzazione dei territori produttivi veneti, Venezia: Marcilio, pp. 71-94.

Sen, A. (2009) The Idea of Justice, Cambridge, MA: Harvard University Press.

Sevilla-Buitrago, A. (2015a) "Espacialidades indignadas: la producción del espacio público en la \#spanishrevolution", ACME: An International Journal for Critical Geographies, 14(1) (online open access).

Sevilla-Buitrago, A. (2015b) "Crisis and the city. Neoliberalism, austerity planning and the production of space", in: Echardt, F. , Ruiz-Sánchez, J. (eds) City of Crisis. The Multiple Contestation of Southern European Cities, Bielefeld: Transcript Verlag, pp. 31-49.

Siatitsa, D. (2014) Claims for the right to housing in cities of Southern Europe: the discourse and the role of social movements, PhD Dissertation, Department of Urban Planning, NTUA, Athens (in Greek).

Silva, R. (2013) "Housing crisis in Portugal", Geographies, 22: 49-51.

Simonazzi, A. , Ginzburg, A. , Nocella, G. (2013) "Economic relations between Germany and southern Europe", Cambridge Journal of Economics, 37: 653-675.

Skidelsky, R. (2013) "Four Fallacies of the second Great Depression", www.projectsyndicate.org/commentary/robert-skidelsky-explains.

Skordili, S. (1999) Geographical restructuring of manufacturing: the case of the food sector in Greece, PhD Dissertation, Department of Planning and Regional Development, AUTH (in Greek).

Skordili, S. (2013) "Economic crisis as a catalyst for food planning in Athens", International Planning Studies, 18(1): 129-141.

Smith, A. (2013) "Europe and an inter-dependent world: uneven geo-economic and geo-political developments", European Urban and Regional Studies, 20(1): 3-13.

Smith, A. (2015) "Macro-regional integration, the frontiers of capital and the externalization of economic governance", Transactions of the IBG, 40(4): 507-522.

Smith, A. , Rainnie, A. , Dunford, M. , Hardy, J. , Hudson, R. , Sadler, D. (2002) "Networks of value, commodities and regions: reworking divisions of labour in macro-regional economies", Progress in Human Geography, 26(1): 41-63.

Smith, G. (1999) Confronting the Present: Towards a Politically Engaged Anthropology, Oxford: Berg.

Soja, E. (2010) Seeking Spatial Justice, Minneapolis: University of Minnesota Press.

Soltas, E. (2015) "The Madre of All Bubbles", http://evansoltas.com/2015/04/03/the-madre-ofall-bubbles/.

Sotiropoulou, I. (2012) Exchange networks and parallel currencies: theoretical approaches and the case of Greece, PhD Dissertation, Department of Economics, University of Greece:

Rethymno (in Greek).

Spourdalakis, M. (1988) The Rise of the Greek Socialist Party, London: Routledge.

Standing, G. (2016) The Corruption of Capitalism. Why Rentiers Thrive and Work Does Not

Pay, London: Bite back Publication.

Stavridis, St . (2017) "Life after the squares: reflections on the consequences of the occupy movements" (intervention on Syntagma), Social Movements Studies, 16(1): 119-151.

Stockhammer, E. (2014) "The Euro crisis and contradictions of neoliberalism in Europe", Post Keynesian Economics Study Group, Working Paper 1401, www.postkeynesian.net.

Storper, M. (1997) The Regional World: Territorial Development in a Global Economy, New York: Guilford.

Sweezy, P. (1994) "The triumph of financial capital", Monthly Review, 46(2): 1-11.

Swyngedouw, E. (1977a) "Excluding the other: the production of scale and the scaled politics", in: Lee, R. , Wills, J. (eds) Geographies of Economies, London: E. Arnold, pp. 167-176.

Swyngedouw, E. (1977b) "Neither global nor local: "glocalization" and the politics of scale", in: Cox, K. (ed) Spaces of Globalization, New York: Guilford, pp. 137-166.

Swyngedouw, E. (2000) "Authoritarian governance, power and the politics of rescaling", Environment and Planning D: Society and Space, 18: 63-76.

Taibo, C. (2013) "The Spanish indignados: a movement with two souls", European Urban and Regional Studies, 20(1): 155-158.

Tarpagos, A. (2010) "The construction sector: from the 'golden decade' to over-accumulation crisis and disaster in Greece", Theseis, 113: 33-41 (in Greek). 
Thirwall, T. (2000) The Euro and Regional Divergence in Europe, London: New Europe Research Trust.

Thoidou, E. , Foutakis, D. (2006) "Metropolitan Thessaloniki and urban competitiveness: programming, transformation and implementation of a 'vision' for the city", Geographies, 12: 25-46 (in Greek).

Todl, G. (2000) "EU regional policy in southern periphery: lessons for the future", South European Society and Politics, 3(1): 93-129.

Trikliminiotis, N. , Parsanoglou, D. , Tsianos, V. (eds) (2015) Mobile Commons, Migrant Digitalities and the Right to the City, London: Palgrave MacMillan.

Vaiou, D. (1997) "Informal cities? Women's work and informal activities on the margins of the European Union", in: Lee, R. , Wills, J. (eds) Geographies of Economies, London: Arnold, pp. 321-330.

Vaiou, D. (2014) "Tracing aspect of the Greek crisis in cities: putting women in the picture", European Urban and Regional Studies, 23(3): 220-230.

Vaiou, D. , Hadjimichalis, C. (2004) With the sewing machine in the kitchen and the Poles in the fields. Cities, regions and informal work, Athens: Exandas (2nd editions, in Greek)

Vaiou, D. , Hadjimichalis, C. (2012) Space in Left Thought, Athens: Nissos/N.Poulantzas Institute (in Greek).

Vaiou, D. , Kalandides, A. (2016) "Practices of collective action and solidarity: reconfigurations of the public space in crisis-ridden Athens, Greece", Journal of Housing and the Built

Environment, 31: 457-470.

Vaiou, D. , Kalandides, A. (2017) "Practices of solidarity in Athens: reconfigurations of public space and urban citizenship", Citizenship Studies, 21(4): 440-454.

Vaiou, D. et al. (2007) Intersecting Patterns of Everyday Life and Socio-Spatial Transformations in the City. Migrant and Local Women in the Neighbourhoods of Athens, Athens: L-Press and NTUA.

Valverde, C. (2013) No nos lo creemos. Una lectura crítica del lenguaje neoliberal, Barcelona: Icaria.

Van Vossole, J. (2014) "Framing PIGS to clean their own stable". Paper presented at 7th ECPR Conference, Bordeaux, France.

Varoufakis, Y. (2011) The Global Minotaur. America, Europe and the Future of the Global Economy, London: Zed Books.

Varoufakis, Y. (2016) And the Weak Suffer What They Must? Europe's Crisis and America's Economic Future, New York: Nation Books.

Vatavali, F. , Chatzikonstantinou, E. (2015) Geographies of energy poverty in Athens in the context of the crisis. (in Greek) www.latsis-foundation.org/eng/education-science-

culture/science/grants/scientific-projects/2015/geographies-of-energy-poverty-in-athens-in-thecontext-of-crisis.

Vatavali, F. , Koutrolikou, P. , Balabanidis, D. , Siatitsa, D. (2013) "Crisis regimes and emerging social movements in Southern Europe: urban development, housing and local struggles",

Geographies, 22: 33-34 (in Greek).

Vathakou, E. (2015) "Citizens' solidarity initiatives in Greece during the financial crisis", in: Huliaras, A. , Clark, J. (eds) Austerity and the Third Sector in Greece: Civil Society at the European Front Line, Aldershot: Ashgate, pp. 167-192.

Vàzquez-Barquero, A. (1992) "Local development and flexible accumulation: learning from history and policy", in: Garofoli, G. (ed) Endogenous Development and Southern Europe, Aldershot: Avebury, pp. 31-48.

Velegrakis, G. (2015) "Cold mining in Chalkidiki and local struggles: analysis of voting practices in municipal and national elections", Geographies, 26: 77-92 (in Greek).

Venables, A. (1996) "Equilibrium locations of vertically linked industries", International Economic Review, 37: 341-359.

Venturini, A. (1988) "An interpretation of Mediterranean migrations", Labour, 2: 125-154.

Verducci, F. (2003) "Immigrazione e mutamento sociale. Lavoro ed integrazione sociale nel distretto industriale della calzatura", Universita deglli Studi di Macerata, Dip. Di Sociologia (mimeo).

Vradis, A. , Dalakoglou, D. (2011) Revolt and Crisis in Greece, Oakland/Edinburgh: AK Press. Wallerstein, I. (1983) Historical Capitalism, London: Verso. 
Weeks, J. (2014) "Euro crises and Euro scams: trade not debt and deficits tell the tale", Review of Political Economy, 26(2): 171-189.

West, R. (1982) Black Lamb and Grey Flacon: A Journey through Yugoslavia, New York: Penguin.

Williams, A. (ed) (1984) Southern Europe Transformed, Cambridge: Harper\&Row.

Wilson, J. , Swyngedouw, E. (2015) "Seeds of dystopia: post-politics and the return of the political", in: Wilson, J. , Swyngedouw, E. (eds) The Post-Political and Its Discontents, Edinburgh: Edinburgh University Press, pp. 1-22.

Ybarra, J.A. , San Miguel, B. , Hurtado, J. , Santa Maria, J . (2004) El calzado en el Vinalopó entre la condinuidad y ruptura, University Alicante: Alicante.

Zavos, A. , Koutrolikou, P. , Siatitsa, D. (2017) "Changing landscapes of urban citizenship: Southern Europe in times of crisis", Citizenship Studies, 21(4): 379-392. 